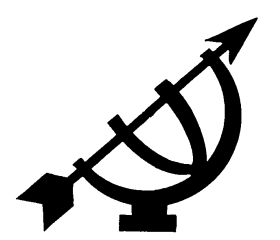

\title{
Godsdiensregte in die regspraak: uitlegmetodes in die CESA-beslissings
}

\author{
J. Swanepoel
}

Fakulteit Regte

Potchefstroomkampus

Noordwes-Universiteit

POTCHEFSTROOM

E-pos: prfjs@puk.ac.za

\begin{abstract}
Religious rights in case law: Methods of interpretation in the CESA judgments
\end{abstract}

In this article an investigation is conducted into the methods of interpretation followed by specific courts in the adjudication of disputes concerning rights pertaining to religion. This inquiry takes place against the backdrop of an exposition of the protection of the rights concerning religion in the Constitution, 1996. The divergent methods followed by the High Court and the Constitutional Court in deciding the application and appeal of Christian Education South Africa respectively are analysed, characterised and compared. The merits and weaknesses of the methods followed by the courts in this case are highlighted. This assessment is made against the background of the question whether persons who take their religious convictions seriously may have the expectation that their rights concerning religion will be effectively protected by South African courts.

Opsomming

Godsdiensregte in die regspraak: uitlegmetodes in die CESA-beslissings

In hierdie artikel word ondersoek ingestel na die uitlegmetodes wat bepaalde Suid-Afrikaanse howe gevolg het in die beregting van dispute oor godsdiensregte. Hierdie ondersoek word gedoen teen die agtergrond van 'n uiteensetting van die beskerming van godsdiensregte in die Grondwet van 1996. Die uiteenlopende uitlegmetodes wat die Hooggeregshof en die Konstitusionele Hof in respektiewelik die aansoek en appèl van Christian Education South Africa gevolg het, word geanaliseer, getipeer en met mekaar vergelyk. Die verdienstes en swakhede verbonde aan die gekose metodes word toegelig teen die agtergrond van die vraag of persone wat hul 
godsdienstige oortuigings ernstig opneem kan verwag dat hul godsdiensregte effektief deur Suid-Afrikaanse howe beskerm sal word.

\section{Inleiding}

Die reg op godsdiensvryheid word in die nuwe Suid-Afrikaanse grondwetlike bedeling as 'n fundamentele reg erken. In die 1993- (of sogenaamde Interim-) Grondwet is hierdie beskerming in artikel 14 vervat, terwyl dit in die 1996- (of sogenaamde Finale) Grondwet beskerm word deur artikels 15 en 31. Die beskerming van die reg op godsdiensvryheid, of - breër geformuleer - van godsdiensregte (sg. religious rights), het oor die afgelope dekade in 'n aantal opspraakwekkende sake voor die Hooggeregshof, die Hoogste Hof van Appèl en die Konstitusionele Hof gekom vir beregting. ${ }^{1}$

In hierdie artikel sal die aandag pertinent gevestig word op 'n regsgeding waarin 'n bepaalde Christelike groepering, Christian Education South Africa (hierna CESA), hom na die Hooggeregshof en later na die Konstitusionele Hof gewend het om sy en sy lede se reg op godsdienstige en kulturele regte te beskerm. ${ }^{2}$ Die oogmerk is spesifiek om aan te toon op watter uiteenlopende wyses die betrokke howe met hierdie reg omgegaan het, om die breë benadering en uitlegmetodes wat die twee howe gevolg het met mekaar te vergelyk en om standpunt in te neem oor die vraag of die gekose werkwyses die effektiewe beskerming van persone se godsdiensregte dien. Op ' $n$ meer algemene vlak sal bespreking gevoer word oor die vraag of persone wat hul godsdienstige oortuigings baie ernstig opneem - hulle na wie daar in die literatuur as obdurate believers verwys word (kyk Bradney, 2000:91) vertroue daarin kan hê dat hulle 'n billike kans op sukses het as hulle die Suid-Afrikaanse howe nader om hul godsdiensvryheid te beskerm.

$1 \quad$ Hierdie navorsing vorm deel van 'n omvattende projek oor die beskerming van godsdiensregte in Suid-Afrika. Daar word in die vooruitsig gestel om ander belangrike uitsprake - soos die Prince- en Lawrence-gewysdes in latere artikels te behandel.

2 Die aansoek by die Hooggeregshof is voorafgegaan deur ' $n$ aansoek om direkte toegang tot die Konstitusionele Hof wat op prosedurele gronde deur hierdie Hof afgewys is (Christian Education South Africa v Minister of Education 199812 BCLR $1449(\mathrm{KH})$ ). Hierna is eers die Hooggeregshof en daarna die Konstitusionele Hof oor die substansie van die saak genader. 
'n Vergelykende bespreking van die uitlegmetodes wat deur die twee howe gevolg is, kan verhelderend wees, veral omdat die SuidAfrikaanse regspraak oor godsdiensvryheid in die nuwe staatkundige bedeling nog in sy kinderskoene staan. Volgens die uitspraak van akademiese skrywers het die Suid-Afrikaanse regspraak oor godsdiensvryheid nog nie eens die moeilike vrae gestel nie - wat nog te sê beantwoord (De Waal, Currie \& Erasmus, 2001:295).

Hierdie ondersoek lê op die terrein van die grondwetlike hermeneutiek. Vir die doel van hierdie artikel kan dit omskryf word as die wetenskap wat hom besig hou met die verstaan van grondwetlike interpretasie. Grondwetlike interpretasie word op sy beurt deur Botha (2005:132) omskryf as " ... the authoratative interpretation of the supreme Constitution by the judiciary during judicial review of the constitutionality of legislation and government action." Grondwetlike hermeneutiek word in die regspraak getipeer as 'n eiesoortige hermeneutiek, wat sy eie metodes vereis en hom met breë beginsels eerder as blote detailinterpretasie van regstekste besig hou (vgl. S v Zuma 1995 (2) SA 642 (K) par. 14). Op die terrein van die hermeneutiek kan daar onderskei word tussen breë benaderings en die metodes waarvolgens hermeneutiese ondersoek onderneem word. Alhoewel die soort metode wat 'n regter of hof gebruik in verband staan met die benadering waarbinne die betrokke regter of hof werk, is dit raadsaam om tussen hermeneutiese benadering en hermeneutiese uitlegmetode te onderskei. Die opbloei van die hermeneutiek in verskeie wetenskappe sedert die laat-twintigste eeu (as teenreaksie op die positivisme) het hom ook op die terrein van die reg kenbaar gemaak. Akademici (soos Devenish, Du Plessis, De Ville, Botha en andere) het verskeie interpretasieteorieë, -benaderings en -metodes of -strategieë onderskei, waarvan daar ook in die regspraak melding gemaak is (vgl. byvoorbeeld Qozeleni v Minister of Law and Order and Another 1994 (3) SA 625 (OK) en S v Zuma and Others 1995 (2) SA $642(\mathrm{~K})$ ). Daar het tot dusver vyf hoofbenaderings uitgekristalliseer, naamlik dié van grammatikale, sistematiese/ kontekstuele, teleologiese/doelbewuste, historiese en vergelykende interpretasie. Die sterker toespitsing op hermeneutiese aangeleenthede hou ook verband met Suid-Afrika se oorgang na 'n demokratiese bedeling. In hierdie proses is die ou uitlegmetodes van die preregstaatlike bedeling deur Froneman $\mathrm{R}$ in die Qozelenisaak (1994 (1) BCLR 75 (OK)) geïdentifiseer as die mischief wat oorkom moet word. In die plek van die vorige benaderings moes oorbeweeg word na 'n wyse van uitleg, wat getuig van substantiewe 
konstitusionalisme en wat deursuur is van die grondwetlike waardes van menswaardigheid, gelykheid en vryheid.

Terwyl 'n sistematisering van die verskillende interpretasiemetodes ongetwyfeld akademiese nut het, het regters by meer as een geleentheid voorbehoude uitgespreek oor die nut van sodanige kategorisering van benaderings ${ }^{3}$. Regters het te kenne gegee dat howe hulle nie sonder meer tot 'n bepaalde metode kan verbind nie. Hierdie huiwerigheid hou verband met die welbekende praktyk van regters om ' $n$ tipe openheid te behou en in 'n bepaalde saak pragmaties die metode te kies wat hom die beste tot die beregting van die saak leen.

\section{Breëre konteks}

\section{1 'n Lang geskiedenis}

Die probleme met betrekking tot die beskerming van godsdiensvryheid het 'n lang en bloedige geskiedenis (Robertson, 1997:202). Dit word algemeen erken dat die stryd om die erkenning van godsdiensvryheid een van die belangrikste faktore was wat aanleiding gegee het tot die ontwikkeling van 'n kultuur van die beskerming van menseregte. Dit is ook wyd bekend dat juis die vervolging van Protestantse Christene tydens die Reformasie ' $n$ belangrike impuls was vir die totstandkoming van 'n bedeling waarin

Kyk Froneman $\mathrm{R}$ se opmerking (Qozeleni $v$ Minister of Law and Order and Another 1994 (3) SA 625 (OK)): "In my view it serves little purpose to characterise the proper approach to constitutional interpretation as liberal, generous, purposive or the like. These labels do not in themselves assist in the interpretation process and carry the danger of introducing concepts or notions associated with them which may not find expression in the Constitution itself. Far more useful is to recognise that because the Constitution is the supreme law of the land against which all law or conduct is to be tested, it must be examined with a view to extracting from it those principles or values against which such law or conduct can be measured." Marais R uiter 'n soortgelyke standpunt (Nortje v Attorney-General of the Cape 19952 SA 460 (K) 472F-G): "[T]he approaches adopted by other Courts and constitutional lawyers to the interpretation, limitation and application of constitutionally entrenched rights are undoubtedly a valuable aid to understanding what is entailed in those processes. Logically structured and systematic approaches have an inherent appeal for lawyers. However, they remain what they are, not holy writ, but simply methodological approaches which are not necessarily the only legitimate approaches to the task ... I regard it as unwise to settle too dogmatically now on one methodology at this very early and embryonic stage of applying our newly devised Constitution to concrete situations. Indeed, it is questionable whether it would be wise to do so at any stage." 
ernstige pogings aangewend is om persone se godsdiensvryheid te beskerm (De Waal, Currie \& Erasmus, 2001:288).

\subsection{Teologiese en juridiese beklemtonings}

In teologiese kringe is die besinning oor godsdiensregte meestal toegespits op twee verbandhoudende, maar onderskeibare vraagstukke. Die vraagstukke is dié van godsdiensvryheid en dié van godsdiensgelykheid. Alhoewel denkers vanuit die Christelike tradisie nie uit een mond hieroor gepraat het nie, $\mathbf{4}$ het daar geleidelik 'n Reformatoriese standpunt hieroor gekristalliseer. Die hooflyn hiervan is dat godsdiensvryheid gerespekteer moet word as iets wat elke persoon toekom, maar dat godsdiensvryheid nie inhou dat alle godsdienste as van dieselfde waarde geag word nie.

In juridiese kringe lê die klem anders. Die reg op godsdiensvryheid staan hier in die sentrum en nie die dogmatiese of leerstellige vraagstuk van godsdiensgelykheid nie. 5 Kwessies oor godsdiensvryheid staan dikwels in verband met gelykheid en word in SuidAfrika onder die gelykheidsartikel (art. 9 van die Grondwet, 1996) gehanteer en nie as leerstellige aangeleentheid nie. Wanneer in gedagte gehou word dat die strewe na die bevordering van gelykheid een van die belangrike tendense in Westerse demokrasieë is, veral sedert die twintigste eeu, en deur sommige as die essensie van geregtigheid beskou word (vgl. Hosten, 1995:20, 32) is die verskil tussen teologiese en juridiese toespitsings geensins verrassend nie. Hierdie verskil is te wagte as in ag geneem word dat state - en gevolglik ook regstelsels - 'n verpligting het om na die regte en belange van al die inwoners van 'n land om te sien.

\subsection{Meer as 'n persoonlike aangeleentheid}

Daar is in sommige kringe - veral in liberalistiese en piëtistiese kringe - 'n neiging om godsdiens en godsdiensbelewing tot die private sfeer te relegeer. Howe lê ook soms klem op die persoonlike

$4 \quad$ Vir 'n uiteensetting van vier modelle oor die verhouding tussen kerk en staat en vir die konsekwensies wat sodanige modelle inhou vir opvattings oor godsdiensvryheid, vgl. Vorster (2004:195-223).

5 Gelykheidskwessies met betrekking tot godsdiens kan natuurlik ook in die reg voorkom en sal dan onder die gelykheidsartikel van die 1996-Grondwet, artikel 9 , hanteer word. Dit is egter dan nie 'n leerstellige aangeleentheid nie. 
aard van godsdiens, 6 al is godsdiensvryheid uiteraard nie 'n suiwer persoonlike of private aangeleentheid nie. Hierdie klem geskied, omdat sodanige reg ook implikasies inhou vir wat die staat te doen staan as daar konflik oor godsdiensregte in sy regsgebied ontstaan, of as die staat dit in die openbare belang ag om persone se godsdiensregte te beperk. Daar moet in gedagte gehou word dat 'n persoon se uitoefening van sy reg op godsdiensvryheid hom of haar in botsing mag bring met die staat en ander persone. lemand wat bepaalde geloofsopvattings huldig, mag byvoorbeeld daarop aanspraak maak om vrygestel te word van die nakoming van algemene reëls wat deur die staat vir al sy burgers neergelê is. Dit kan ook gebeur dat persone, wanneer sodanige vrystelling nie verleen word nie, mag weier om wette te gehoorsaam wat hulle as in botsing met hul geloof of godsdiens beskou.

\subsection{Drie benaderingswyses}

State het deur die loop van die eeue verskillende benaderingswyses gevolg tot die beskerming van godsdiensregte. In ons eie tyd kom daar ook verskeie hanteringswyses daarvan voor, waarvan die belangrikstes die volgende is:

- om staat en kerk (regering en godsdiens) streng en netjies te skei;

- om 'n staatsgodsdiens te erken; en

- om te poog om redelike akkommodering van persone se geloofsoortuigings deur die staat te verseker.

6 In S v Lawrence laat Sachs R, met verwysing na die 1993-Grondwet, hom soos volg uit oor die doel van die godsdiensartikel:

To my mind, read in the context of all of the above provisions and of the Constitution as a whole, s 14 was intended at least to uphold the following principles and values: South Africa is an open and democratic society with a non-sectarian State that guarantees freedom of worship; is respectful and accommodatory towards, rather than hostile to or walled-off from, religion; acknowledges the multifaith and multi-belief nature of the country; does not favour one religious creed or doctrinal truth above another; accepts the intensely personal nature of individual conscience and affirms the intrinsically voluntary and non-coerced character of belief; respects the rights of non-believers; and does not impose orthodoxies of thought or require conformity of conduct in terms of any particular world-view [147] (kursivering - JS). 
'n Voorbeeld van eersgenoemde benadering word aangetref in die regstelsel van die Verenigde State van Amerika. Alhoewel dit kennelik die oogmerk van die Amerikaanse Grondwet was om met die eerste amendement tot die Grondwet - met sy sogenaamde institusionele bepaling (establishment clause) en sy vryebeoefeningsbepaling (free exercise clause) - godsdiensvryheid te beskerm, het dit globaal genome die teenoorgestelde uitwerking gehad (Currie \& De Waal, 2005:337). Dit het in werklikheid daartoe bygedra om godsdiens uit die openbare sfeer te weer. Afgesien hiervan het hierdie skeidingsbenadering tot uitgebreide en komplekse litigasie met verrassende uitsprake aanleiding gegee. ${ }^{7}$ Die tweede benadering is tans minder gebruiklik as tevore in die meeste moderne Westerse liberale demokrasieë8. Dit kom veral in sommige Islamitiese state voor, byvoorbeeld in Marokko (soos blyk uit artikel 6 van die Marokkaanse Grondwet wat bepaal: "Islam shall be the state religion. The state shall guarantee freedom of worship for all" - kyk ook Robertson, 1997:177). Die derde benadering behels dat staats- en godsdienstige aangeleenthede so ver moontlik duidelik onderskei moet word en dat die tersaaklike instansie of samelewingsverband (die staat of die kerk) die sake moet hanteer wat op sy terrein tuishoort. Waar sodanige onderskeiding nie moontlik is nie, moet sowel die persoon met geloofsoortuigings as die staat ' $n$ redelike akkommodering probeer bereik. Die benadering wat tans in Suid-Afrika gevolg word, val breedweg binne die raamwerk van die derde benadering, soos blyk uit artikel 15(2) van die Grondwet, 1996 (vgl. Woolman aangehaal in Chaskalson et al.,1999:19.2).

\subsection{Die enger Suid-Afrikaanse konteks}

Dit is ook belangrik om die spesifiek Suid-Afrikaanse konteks te verstaan waarin gedinge oor godsdiensregte tans plaasvind. Daar moet in gedagte gehou word dat Suid-Afrika sedert 1994 'n grondwetlike demokrasie en regstaat is wat menswaardigheid,

7 'n Bakensaak in hierdie verband is Lemon v Kurtzman (403 US 602 (1970)). Hierin het die Hof die vereistes neergelê waaraan 'n wet moet beantwoord om aan die institusionele bepaling te voldoen. Die vereistes is dat ' $n$ wet ' $n$ sekulêre wetgewende doel moet hê, dat dit 'n hoofeffek moet hê wat godsdiens nóg moet beperk nóg moet bevorder, en dat dit nie oormatige staatbetrokkenheid by godsdiens in die hand moet werk nie.

8 Dat hierdie tipering nie van toepassing is op alle Westerse liberale demokrasieë nie, blyk uit die posisie van die Church of England in die grondwetlike bestel van die Verenigde Koninkryk. 
gelykheid en vryheid as kernwaardes, maar ook as beregbare regte in sy Grondwet erken. Daar is 'n uitgesproke begeerte om SuidAfrika in 'n oop en demokratiese samelewing te ontwikkel, waarin daar ' $n$ verbondenheid tot bogenoemde kernwaardes aanwysbaar is (vgl. veral artikels 1(a), 7(1), 9, 10, 12 en 36(1) van die 1996Grondwet) en waarin verdraagsaamheid en respek vir verskeidenheid of pluralisme voorkom. ${ }^{9}$ Die nuwe grondwetlike bedeling word voorgehou as een wat 'n radikale breuk met die verlede verteenwoordig. So ver dit godsdienstige aangeleenthede aangaan, beteken dit spesifiek ' $n$ breuk met die apartheidsverlede en sy bevoordeling van die Christelike godsdiens - in besonder die Protestants-Christelike variante daarvan. Hierdie eertydse bevoordeling is in die na-grondwetlike bedeling nie meer aanvaarbaar nie, aangesien dit in stryd is met die gelykheidsbepaling (artikel 9 van die Grondwet, 1996) en omdat dit beskou word as iets wat menswaardigheid aantas, deurdat dit die godsdienstige oortuigings van sommige persone hoër as dié van ander ag. (Vgl. die uitspraak van O'Regan $\mathrm{R}$ in die Lawrence-saak in die Konstitusionele Hof, par. 123: O'Regan $\mathrm{R}$ wys daarop dat die eertydse bevoordeling van die Christelike godsdiens op indirekte dwang op nie-Christene neerkom.)

\section{Grondwetlike beskerming}

Daar is in die inleidingsparagraaf van hierdie artikel daarop gewys dat die godsdiensregte op verskillende wyses beskerm is in die 1993- en 1996-Grondwette. In die 1993-Grondwet is dit beskerm deur artikel 14, wat betrekking gehad het op vryheid van godsdiens, van uitdrukking en van gewete. Hierby is die beskerming van akademiese vryheid ingesluit. Indien 'n wet godsdienstige oortuigings en gedrag substantief beperk, het die beperkingsartikel artikel 33 van die 1993-Grondwet - in werking getree. Ingevolge artikel 33(1)(b) sou sodanige beperking slegs geldig wees indien dit nie net redelik nie, maar ook noodsaaklik was in 'n demokratiese gemeenskap (vgl. Chaskalson et al., 1999:19.2).

9 In paragraaf 79 van die uitspraak van Ngcobo $\mathrm{R}$ in die Prince-saak in die Konstitusionele Hof, verwys hy na verdraagsaamheid as ' $n$ implisiete waarde in die Grondwet en in paragraaf 49 wys hy daarop dat diversiteit in die SuidAfrikaanse samelewing gerespekteer en gekoester moet word. Vgl. ook Sachs $\mathrm{R}$ se opmerking in paragraaf 23 van die CESA-saak in die Konstitusionele Hof, waar hy opmerk: "Moreover, if society is to be open and democratic in the fullest sense it needs to be tolerant and accepting of cultural pluralism." 
In die 1996-Grondwet word twee artikels gewy aan die beskerming van godsdiensregte - artikel 15 (wat breedweg gesproke dieselfde strukturele geledinge as artikel 14 in die 1993-Grondwet vertoon, maar in ander opsigte beduidend daarvan verskil10) en artikel 31, wat ' $n$ nuwigheid in die 1996-Grondwet is. 11 Artikel 14 van die 1993en artikel 15 van die 1996-Grondwet is wyd geformuleer en is toegespits op die beskerming van 'n persoon se reg op vryheid van gewete, godsdiens, denke, oortuiging en mening. ${ }^{12}$ Woolman (in Chaskalson et al., 1999:19.1) wys daarop dat die verlening van godsdiensvryheid tradisionele godsdiensstelsels beskerm, terwyl die verwysing na gewetensvryheid op die oorblywende stel etiese "belief systems" betrekking het.

Die reg op godsdiensvryheid is deur die Konstitusionele Hof - in aansluiting by Kanadese regspraak ( $R \vee$ Big M Drug Mart 18 DLR (4th) 321, 1 SCR 295) - uitgelê as 'n reg van 'n persoon om sonder dwang bepaalde opvattings te huldig (vgl. Woolman aangehaal in Chaskalson et al., 1999:19.15 en die Lawrence-uitspraak 1208 E 1209A). Hierdie reg op godsdiensvryheid sluit ook die reg in om sodanige godsdiens te propageer en om godsdienstige oortuigings in aanbidding (worship) en praktyk te manifesteer. Godsdiensvryheid word op positiewe en negatiewe wyse teen inbreukmaking daarop beskerm. Die toets of ' $n$ wet godsdiensvryheid direk of indirek aantas, is of sodanige wet 'n substantiewe las op godsdiensvryheid plaas (vgl. Woolman, aangehaal in Chaskalson et al. Constitutional Law, 1999:19.2: "The test for any law should be whether it substantially burdens religious freedom").

Die belangrikste verskil is daarin geleë dat die godsdiensbepaling in die 1996Grondwet onderhewig gestel is aan artikel 8, die sogenaamde toepassingsklousule. Woolman (aangehaal in Chaskalson et al., 1999:19.7) stel dit soos volg: "The new section of the Bill of Rights (s 8) broadens the ambit of religious freedom by binding parties that were not bound by Chapter 3 of the interim Constitution. Religious organizations are now also bound by the equality provision and perhaps by other sections of Chapter 2."

11 Vir die doeleindes van 'n vergelykende bespreking van die uitlegmetodes in die CESA-sake, word die aandag hier toegespits op artikel 14(1) van die 1993- en artikel 15(1) van die 1996-Grondwet en word daar nie ingegaan op 14(2) en (3) en 15(2) en (3) nie.

12 Akademiese vryheid is in die 1993-Grondwet in artikel 14 beskerm. In die 1996Grondwet word dit beskerm deur artikel 16, wat betrekking het op vryheid van uitdrukking. Vir die ratio hieragter, vergelyk Woolman soos aangehaal deur Chaskalson et al. (1999:19.9). 
Terwyl artikel 15, soos die oorgrote meerderheid bepalings in die Handves van Regte, positief geformuleer is, tref ons in artikel 31 'n negatiewe formulering aan:

31(1) Persone wat aan 'n kultuur-, godsdiens- of taalgemeenskap behoort, mag nie die reg ontsê word om, saam met ander lede van daardie gemeenskap -

(a) hul kultuur te geniet, hul godsdiens te beoefen en hul taal te gebruik nie, en

(b) kultuur-, godsdiens- en taalverenigings en ander organe van die burgerlike gemeenskap te vorm, in stand te hou en daarby aan te sluit nie.

(2) Die regte in subartikel (1) mag nie uitgeoefen word op 'n wyse wat met enige bepaling van die Handves van Regte onbestaanbaar is nie.

Die nuutingevoerde artikel 31 het kennelik betrekking op die publieke en openbare manifestasies van die uitoefening van godsdiensregte. In die lig hiervan, doen Pieterse (2000:310) aan die hand dat artikel 15 voortaan net residueel van belang sal wees by gedinge oor godsdiensbeoefening.

Op grond van bogenoemde uiteensetting kan duidelik gesien word dat die reg op godsdiensvryheid in artikel 31 nie afsonderlik nie, maar in samehang met ander regte, naamlik dié van kultuur- en taalgemeenskappe, beskerm word. Dit is ook met die eerste oogopslag duidelik dat die Grondwet van Suid-Afrika 'n heel ander koers ingeslaan het as die Amerikaanse reg, wat 'n streng skeiding tussen kerk en staat handhaaf. Dit is van besondere belang om op te merk dat die Suid-Afrikaanse Grondwet nie sogenaamde groepsof minderheidsregte beskerm nie, maar wel die regte van individuele persone wat tot godsdienstige gemeenskappe behoort. Waar die fokus in artikel 15 lê op godsdienstige oortuigings en die beoefening daarvan, gaan dit in artikel 31 om die beskerming van 'n persoon se godsdiensbeoefening saam met ander persone wat tot so 'n gemeenskap behoort. Dit het met ander woorde betrekking op die regte wat ' $n$ individuele persoon toekom, maar wat slegs in ' $n$ gemeenskap tot uitdrukking kom en beoefen kan word.

Daar moet verder opgelet word dat die regte in artikel 31(1) duidelik gekwalifiseer word deur artikel 31(2). Laasgenoemde bepaal dat die regte wat in 31(1) verleen word, nie uitgeoefen mag word op 'n wyse wat strydig is met enige bepaling van die Handves van Regte, soos vervat in Hoofstuk 2 van die Grondwet, 1996, nie. Die implikasie hiervan is dat artikel 31(1) nie so ver strek dat dit gods- 
diensbeoefening as 't ware privatiseer en uit die openbare sfeer verwyder nie. Die artikel stel godsdiensbeoefening pertinent bloot aan grondwetlike kontrole/toetsing (scrutiny).

Dit blyk dus duidelik dat die Suid-Afrikaanse Grondwet nie godsdiensonverskillig is nie. Op grond van 'n ontleding van grondwetlike bepalings in verband met godsdiens is dit duidelik dat hier nie soos soms verkeerdelik beweer word - met 'n sekulêre staats- en godsdiensbeskouing gewerk word nie. Suid-Afrika het 'n Grondwet wat op verskeie wyses erkenning verleen aan godsdiens en wat ruimte skep vir die respektering van die oortuigings van alle persone. Dit geld sowel die oortuigings van diegene wat bepaalde godsdienstige opvattings huldig as van dié van persone wat geen sodanige oortuigings huldig nie, of wat godsdiens as iets irrelevants beskou. Venter (1998:457) het gelyk wanneer hy opmerk: "The Constitution does not require the state to dissociate itself from religious activity."

Dit is opmerklik dat die regte wat in die 1996-Grondwet in artikels 15 en 31 beskerm word nóú aansluit by die regte vervat in artikel 18 van die Universal Declaration of Human Rights wat in 1948 deur die Verenigde Nasies aanvaar is. Terwyl die regte in die Grondwet van 1996 afsonderlik in twee artikels tot uitdrukking kom, figureer dit in artikel 18 van die VN-deklarasie in dieselfde artikel:

Everyone has the right to freedom of thought, conscience and religion; this right includes freedom to change his religion or belief, and freedom, either alone or in community with others and in public or in private, to manifest his religion or belief in teaching, practice, worship or observance.

\section{Die CESA-beslissings}

\subsection{Uiteenlopende maniere}

In hierdie afdeling sal die aandag toegespits word op 'n bespreking en analise van die twee CESA-beslissings. Sowel die Hooggeregshof as die Konstitusionele Hof was eenstemmig in hul verwerping van respektiewelik CESA se aansoek en appèl. Tog het hulle op heel uiteenlopende maniere tot hierdie beslissings geraak. Die verskillende weë wat die twee howe opgegaan het, verteenwoordig twee uiteenlopende uitlegmetodes in die beregting van sake oor godsdiensregte. 


\subsection{Die feite van die saak}

Die geding het ontstaan na aanleiding van die South African Schools Act wat in 1996 op die wetboek gekom het (Wet 84 van 1996) en in 1997 gepromulgeer is. Artikel 10 daarvan plaas 'n totale verbod op die toediening van lyfstraf op skool, ongeag daarvan of die skool 'n staats- of nie-staatskool is. Die uiteensetting van die feite van die CESA-saak geskied met verwysing na die Hooggeregshofuitspraak, soos gerapporteer in die Suid-Afrikaanse Hofverslae.

Die applikant, CESA, 'n vrywillige vereniging van 196 onafhanklike skole wat hom as regspersoon beywer het vir die bevordering van Christelike opvoeding en vir die handhawing van 'n aktiewe Christelike etos in die leeromgewing, het hom na aanleiding hiervan tot die hof gewend. Hulle het aangevoer dat hierdie bepaling ongrondwetlik en ongeldig is in soverre dit van toepassing gemaak word op onafhanklike skole en op leerders by die spesifieke skole waar ouers of voogde tot die toediening van lyfstraf toegestem het (1096 D-E). Daar is geargumenteer dat die wetsbepaling inbreuk maak op verskeie fundamentele regte waaroor die applikant ingevolge die Grondwet beskik, onder meer op artikels 15(1), 29(3), 30 en 31 . Veral ter sake is artikel 31, naamlik die reg wat persone het om nie verhinder te word om in 'n godsdiensgemeenskap hul godsdienstige oortuigings uit te leef in godsdienstige gebruike nie (1097 G-H). Daar is verder aangevoer dat lyfstraf, soos toegedien in hulle skole, deur die gemenereg gesanksioneer is (1099 I) en deel vorm van die opregte godsdienstige oortuigings en kulturele waardes van ouers, wat lede van die vereniging is (1099 l-J). Die oortuiging met betrekking tot die toediening van lyfstraf is voorgehou as 'n wesenlike element (vital element) van die Christelike geloof, soos wat dit deur lede van die vereniging verstaan en beoefen word (1099 B).

\subsection{Die Hooggeregshof se werkwyse}

Die Hooggeregshof beslis die saak uit hoofde van artikel 3113 en bied 'n uiteensetting van die stappe wat gevolg moet word in 'n dispuut soos die onderhawige een, waar godsdiensvryheid in geding is en die grondwetlikheid van 'n wetsbepaling aangeveg word.

13 Dit is duidelik uit die Hof se bevinding dat die applikant se reg nie op godsdiens as sodanig gegrond is nie. Dit kan hoogstens getipeer word as ' $n$ praktyk wat verband hou met godsdienstige oortuigings (vgl. 959D - 961A). 
Volgens die Hof moet daar eerstens nagegaan word of die oortuiging (belief) waarop die applikant hom beroep deel uitmaak van die godsdiens wat deur die persoon/persone beoefen word en of dit opreg op godsdienstige gronde gehuldig word (1100 I). Om dit vas te stel, kan daar gekyk word na wat die applikant in hierdie verband sê, maar sodanige ipse dixit moet aangevul word deur 'n verstrekking van die gronde wat vir sodanige oortuiging aangevoer word. Hierdie stawing is nodig om te kan beoordeel of daar bewys is dat 'n opregte oortuiging (sincere belief) bestaan het wat op godsdienstige gronde gebaseer is (1101 A-C).

Indien die oortuiging - wat in konflik met die wetsbepaling is inderdaad deel vorm van 'n persoon se godsdienstige oortuigings en daardie oortuigings opreg gehuldig word, moet daar vervolgens vasgestel word of die betrokke wetsbepaling inderdaad 'n las plaas op die persoon wat die aansoek tot die Hof rig. Hierdie toets staan bekend as dié van substantial burden en word in Amerikaanse regspraak aangetref. Daar word in aansluiting by Amerikaanse gesag gestel dat die Hof nie 'n waardebeoordeling moet maak van die aanvaarbaarheid, logika, konsekwentheid/samehangendheid (consistency) en verstaanbaarheid van die bepaalde oortuiging vir ander persone as dié van die betrokke godsdienstige gemeenskap nie (1100 C-D). Hierdie siening word in die Suid-Afrikaanse literatuur oor die aangeleentheid onderskryf (vgl. byvoorbeeld Woolman aangehaal in Chaskalson et al., 1999:19.2 wat stel dat die howe nie aan 'n objektiewe kriterium moet meet of godsdienstige oortuigings redelik en gesofistikeerd is nie).

Toegepas op die feite in die saak, bevind die Hof dat die applikant nie bewys het dat daar 'n opregte oortuiging is, wat op godsdienstige gronde gehuldig word, dat onderwysers in skole die bevoegdheid moet hê om lyfstraf aan leerlinge toe te meet nie (1100 I-J). Terwyl die Hof aantoon dat ouers gemeenregtelik die bevoegdheid het om hul kinders in geval van ongeoorloofde gedrag ter wille van dissiplinering lyfstraf toe te dien, mits dit geregverdig en nie buitensporig is nie (1101 D-E), en dat onderwysers op grond van die verhouding tussen onderwyser en leerling (1101 E-G) 'n soortgelyke reg gehad het, is hierdie onderwysersbevoegdheid nie van delegering daarvan deur die ouer aan die onderwyser afkomstig nie. Om voor te gee dat dit wel die geval is, kom volgens die Hof daarop neer om 'n gemeenregtelike aangeleentheid in godsdienstige gewaad te laat paradeer ("to clothe the rules of common law in religious attire") (1102A). 
Die Hof maak dit duidelik dat die applikant se aansoek reeds in die heel eerste fase van die ondersoek faal, omdat daar nie bewys is dat die oortuiging op godsdienstige gronde gehuldig word nie. Dit was dus streng gesproke nie vir die Hof nodig gewees om die ondersoek verder te voer nie. Die partye het egter reeds voor uitspraak aan die Hof te kenne gegee dat hulle van hierdie geding 'n toetssaak gaan maak; ook dat die party wat die saak verloor na alle waarskynlikheid teen die uitspraak appèl sal aanteken. Die Hof het daarom, steeds binne die eerste konseptuele fase van die ondersoek (vgl. Pieterse, 2000:675), die ondersoek verder gevoer in die veronderstelling dat die applikant wel kon aantoon dat hy op godsdienstige gronde opreg oortuig is dat lyfstraf op skool deur onderwysers toegedien moet word. In so 'n geval is die volgende vraag of die wetsbepaling, substantief gesproke, 'n las op die applikant se godsdiensvryheid plaas (1102 C).

Die korrekte toepassing van hierdie toets behels 'n ondersoek na die effek, uitwerking of impak van die inbreukmaking op die applikant se godsdiensvryheid (1102 E). Sodanige inbreukmaking moet volgens die Hof holisties beoordeel word (1102 D-E). Daar moet met ander woorde nie eng gekyk word na die inbreukmaking op die applikant se vermoë om lyfstraf in skole deur sy onderwysers te laat toedien nie, maar na die impak van so 'n wetsbepaling op die applikant se godsdiensbeoefening oor die algemeen.

'n Bevinding deur die Hof dat 'n wet die godsdiensvryheid van 'n persoon beperk, hou belangrike implikasies in, aangesien dit ' $n$ bewyslasverskuiwing meebring. Die staat dra in so 'n geval die onus om sy wetgewing onder die beperkingsbepaling te regverdig (Du Plessis, 2000:301).

In die toepassing van hierdie been van die toets, bevind die Hof dat die getuienis daarop dui dat die lede van CESA die Bybelse riglyne nie van soveel belang geag het dat die verbod op lyfstraf as ' $n$ substantiewe beswaring van hul godsdiensvryheid aangemerk kan word nie. Die motivering hiervoor is enersyds dat die applikant in hul skole ook van ander dissiplinêre maatreëls benewens lyfstraf gebruik maak, veral ten opsigte van vroulike leerders op hoërskool. Andersyds word bevind dat die skole steeds sonder inmenging kon voortgaan met die opvoeding en onderrig van die leerders binne die kader van hul godsdienstige oortuigings en leer. $\mathrm{Na}$ aanleiding hiervan word beslis dat daar nie 'n substantiewe beswaring van die geloofsoortuigings van die lede van die applikant plaasgevind het nie (1103 D). Die toediening van lyfstraf deur onderwysers kan dus 
as 'n periferale aangeleentheid in die breë konteks van godsdiensbeoefening aangemerk word.

Soos hierbo aangetoon, word die reg in artikel 31(1) gekwalifiseer deur artikel 31(2), wat bepaal dat die reg vervat in subartikel 1 nie uitgeoefen mag word op ' $n$ wyse wat strydig is met enige ander bepaling in die Handves van Regte nie $(1103 \mathrm{H}$ e.v.). Die Hof bevind dat die toediening van lyfstraf - selfs al sou dit spruit uit 'n opregte oortuiging wat deel uitmaak van 'n persoon se godsdienstige oortuigings - strydig is met artikels 10, 12(1)(c), (d) en (e) asook met artikel 28(1)(d) van die 1996-Grondwet. Dit is dus strydig met die bepalings oor menswaardigheid, fisiese integriteit, die vryheid en veiligheid van die persoon en ook met die kind se reg om beskerm te word teen mishandeling, verwaarlosing, misbruik en vernedering. In die lig van hierdie en ander oorwegings, ${ }^{14}$ kon die applikant nie slaag met ' $n$ aansoek wat gebaseer is op die beskerming van sy godsdienstige en kulturele regte nie.

Die slotsom van die hele ondersoek is dat die applikant se aansoek steeds moet faal, selfs al sou dit wel, anders as wat beslis is, gegrond wees op godsdienstige en kulturele gronde.

Hierdie werkwyse wat die Hooggeregshof gevolg het, bring mee dat die algemene beperkingsklousule in die Handves van Regte nie in die oorweging van die dispuut betrek word nie. Dit is so omdat daar nie in die eerste fase van die hofondersoek bewys kon word dat daar 'n aantasting van godsdiensregte plaasgevind het wat ingevolge artikel 36 beoordeel moes word nie.

\subsection{Bespreking}

\subsubsection{Duidelik maar streng}

Die Hooggeregshof het gepoog om in hierdie uitspraak 'n duidelike uitlegmetode neer te lê oor hoe sake van hierdie aard gehanteer behoort te word. Die metode wat gevolg word, word duidelik uiteengesit. Om vas te stel of die applikant 'n bepaalde oortuiging opreg op godsdienstige gronde huldig, bedien die Hof hom van verskillende tegnieke, vernaamlik dié van die analisering van Skrifgedeeltes en van reading down (kyk 4.4.3).

14 Die Hof motiveer verder sy uitspraak deur 'n beroep te doen op tendense in die Volkereg (1105 A-D) en op grondwetlike waardes, waarop daar nie in hierdie artikel dieper ingegaan sal word nie. 
Ten spyte van die konseptuele helderheid daarvan, kan hierdie uitlegmetode terselfdertyd as betreklik streng getipeer word. Dit blyk onder meer daaruit dat die Hof in besonderhede ingaan op die gronde van die applikant se bewering dat lyfstraf deel uitmaak van sy geloofsoortuigings, terwyl die respondente in die saak nie eens die opregtheid van die applikant se oortuigings bevraagteken of in dispuut geplaas het nie. Die strengheid is ook te bemerk in die wyse waarop die Hof die dispuut beredeneer. Die literal reasoning van hierdie benaderingswyse word deur Du Plessis (2000:299) gekritiseer as iets wat onvanpas is by die beregting van dispute oor godsdiensregte.

\subsubsection{Tipering van en kritiek op die uitlegmetode}

In die poging om vas te stel of die oortuiging waarop die applikant hom beroep, deel vorm van sy godsdiens, ontleed die Hof die tekste (Skrifgedeeltes) waarop die applikant hom beroep (Spr. 22:6, 15; 19:18; 23:13-14 asook Deut. 6:4-7 ten opsigte van ouers en Matt. 28:19-20 ten opsigte van die kerk). Die bevinding dat die applikant se oortuigings nie op godsdienstige gronde berus nie, word gebaseer op die feit dat die genoemde tekste slegs van ouers praat en nie van onderwysers nie $(1101 \mathrm{G}-\mathrm{H})$. Hierdie benadering getuig van 'n enge literalisme en is op verskeie gronde kritiseerbaar.

Daar is in die eerste plek min blyke daarvan dat die Hof met sy literalistiese uitleg 'n poging aangewend het om die toediening van lyfstraf te verstaan soos wat die lede wat tot die betrokke godsdienstige gemeenskap behoort, dit verstaan. As die Hof, in 'n gees van doelbewuste interpretasie, hierdie weg opgegaan het, sou hy nie vasgekyk het teen die woorde in die tekste as sodanig nie, maar sou hy gesoek het na die beginsel wat dit onderlê. Hieruit sou blyk dat lyfstraf - of liggaamlike korreksie, soos wat die applikant verkies om dit te noem - binne die betrokke geloofsgemeenskap beskou word as iets wat daarop afgestem is om die kind ten goede te kom en dat dit tot sy/haar behoud en heil gedoen word. Dit is iets wat gemotiveer word deur liefde en nie iets wat aangespoor word deur sadisme of ' $n$ begeerte om te folter nie.

Dit staan die Hof uiteraard vry om hierdie siening te kritiseer en te verwerp. Daar bestaan egter min twyfel daaroor dat ' $n$ werkwyse wat poog om 'n verskynsel as 't ware van binne te verstaan, heelwat meer oorwoë en empaties sou voorkom as die een wat gevolg is, naamlik die letterlike uitleg van tekste, waar die nie-vermelding van onderwysers in die betrokke tekste die deurslag gee. 
Die werkwyse wat die Hooggeregshof hier volg, is in stryd met die uitlegbenadering wat die Konstitusionele Hof in $S v$ Zuma and Others (1995 (2) SA 642 (K)) - 'n leidende gewysde oor grondwetlike hermeneutiek in die Suid-Afrikaanse reg, onderskryf. In die betrokke saak verwys die Hof by monde van waarnemende regter Kentridge in paragraaf 13 met instemming na die dicta van Lord Wilberforce in die Privy Council (in Minister of Home Affairs (Bermuda) $v$ Fisher (1980)). Daar word gestel dat grondwetlike hermeneutiek van gewone hermeneutiek verskil en "a generous interpretation ... suitable to give to individuals the full measure of the fundamental rights and freedoms referred to" verg. Die literalistiese uitleg in die Hooggeregshof uitspraak is glad nie tekenend van so 'n generous approach, wat daarop ingestel is om 'n persoon se reg in volle maat te laat gedy nie.

Alhoewel die Hof in sy uitspraak daarop wys dat oortuigings met die loop van tyd verander soos wat samelewings verander (iets wat treffend geïllustreer word deur 'n verwysing na die oproep tot steniging van ' $n$ opstandige seun in Deut. 21:18-21), is daar min blyke daarvan dat die Hof met toenemende samelewingsdifferensiëring rekening gehou het. As dit wel in ag geneem sou word, sou dit nie so ondenkbaar wees dat bevoegdhede wat deur ouers in die huis uitgeoefen is, in 'n meer gedifferensieerde samelewing deur onderwysers op skool voortgesit word nie - te meer nog in geval van eksplisiete toestemming van die ouers daartoe.

Die Hof het heeltemal gelyk as hy opmerk dat die bevoegdheid van onderwysers om lyfstraf toe te dien uit die gemenereg ontstaan het en nie uit die godsdiens nie. Dit sluit egter nie uit dat ouers, op grond van hul verstaan van die aansprake van hul godsdiens op hulle, mag voel dat hulle op godsdienstige gronde ten gunste van die toediening van lyfstraf is nie. Die feit dat ouers daartoe toestem dat onderwysers lyfstraf op skool toedien, kan gevolglik nie sonder meer beskou word as 'n bewys van hul onopregtheid nie, soos wat die Hof te kenne gee met sy ongelukkige toespeling op 'n Bybelse verwysing na die wolf in skaapsklere (1102A). Terwyl hierdie oortuiging nie stam uit ' $n$ bepaalde teks nie, is dit globaal genome vanuit die perspektief van 'n gelowige wel deel van, of minstens verbandhoudend met, sy/haar godsdienstige oortuigings. Daar moet in gedagte gehou word dat godsdienstige oortuigings in baie Christelike gemeenskappe - baie bepaald in die protestantse lyn 'n effek op veel meer as godsdiens as sodanig uitoefen. Godsdienstige oortuigings het as 't ware 'n suurdeegeffek: gelowiges beskou dit as van deurslaggewende belang, nie net vir hul 
sogenaamde geestelike lewe nie, maar vir die hele lewe, ook vir die breër maatskaplike dimensies daarvan.

\subsubsection{Reading down/Beperkende interpretasie}

Die feit dat die Hof die beperking van godsdiensvryheid holisties benader kan as 'n vorm van reading down getipeer word (vgl. Hogg, 1992:15.7 en 33.6(e) in verband met hierdie vorm van beperkende interpretasie). Du Plessis (2000:298) kritiseer hierdie werkwyse skerp en tipeer dit as een wat godsdiensvryheid skaad. Deur die meeste gewig toe te ken aan 'n ondersoek daarna of die applikant se godsdiensvryheid, globaal genome, aangetas is en nie primêr en pertinent die fokus daarop in te stel of die verbod op lyfstraftoediening deur onderwysers, die applikant se godsdiensvryheid aantas of beperk nie, vereng die Hof die reg op godsdiensvryheid onnodig. Die kritiek aan die hand van Lord Wilberforce se opmerkings, wat met instemming aangehaal is in $S v$ Zuma, en wat in paragraaf 4.4.3 teen die literalisme van die Hooggeregshofuitspraak ingebring is, is mutatis mutandis ook hier van toepassing.

\subsubsection{Ander kritiekpunte}

Alhoewel die Hof te kenne gee dat howe nie die aanvaarbaarheid, logika, samehangendheid en verstaanbaarheid van die bepaalde godsdienstige oortuigings moet beoordeel nie, begeef die Hof hom myns insiens wel op hierdie terrein. Dit blyk uit die bevinding dat Christene wel, skynbaar in stryd met hul verklaarde oortuiging dat lyfstraf noodsaaklik is, onderskei tussen manlike en vroulike leerders en ook die leerders se ouderdom in ag neem. Dit wil my voorkom of die Hof se uitwysing van die applikant se verskillende hantering van manlike en vroulike leerders op 'n ondersoek na die konsekwentheid en logika van die stel oortuigings van 'n geloofsgemeenskap neerkom, alhoewel dit oor die boeg van 'n evaluering van die opregtheid van die applikant se oortuigings gegooi word. Die Hof se hantering van hierdie aangeleentheid is nie in ooreenstemming met die duidelike riglyne wat die Konstitusionele Hof later in die Worcester Muslim Jamaa-uitspraak sou neerlê nie. ${ }^{15}$

15 In Worcester Muslim Jamaa v Valley and Others (2002 (6) BCLR 591 (K) par. 109) formuleer die hof 'n baie versigtige en terughoudende benadering ten opsigte van die beslissing oor godsdienstige kwessies. Die Hof laat hom soos volg daaroor uit:

(a) Unless absolutely necessary, the State speaking through the mouths of its courts, should never attempt to impress its own legal, secular rules 
Weens die streng toets wat in die Hooggeregshof aangelê is, moes die aansoeker daar - waarskynlik tot sy groot verbasing - verneem dat sy bekommernis oor sy godsdiensregte (waaroor hy die moeite gedoen het om hom eers tot die wetgewer en later tot die hof te wend) nie werklik godsdienstig van aard is nie en daarom nie deur die Handves beskerm word nie. Daar word ter oorweging gegee dat die aansoeker hierdie kliniese benadering as hoogs teen-intuïtief sou ervaar.

Daar kan verder, op grond van eie waarneming van albei die situasies, vrae gestel word oor die Hof se debatteerbare gelykstelling van lyfstraf op skool met die lyfstraf vir minderjariges wat kriminele oortredings begaan het (1107 F-J). Verder neig die Hof se assosiëring van lyfstraf met foltering na die hiperboliese, selfs al word hierdie assosiasie gekwalifiseerd vermeld.

Ten slotte kan opgemerk word dat die Hof se uitspraak deur regterlike minimalisme gekenmerk word. Die Hof beslis slegs oor wat voor hom geplaas is, te wete die toelaatbaarheid al dan nie van lyfstraf op skool deur onderwysers. Daar kan gevolglik nie met die Hof se toepassing van hierdie leerstuk fout gevind word nie. Die belangstellende in die Suid-Afrikaanse regsontwikkeling oor lyfstraf sal daarom moet wag dat 'n saak opduik, waar die Hof hom moet uitlaat oor die grondwetlikheid al dan nie van ouers se gemeenregtelike bevoegdheid om in die huislike omgewing lyfstraf aan hulle kinders toe te dien. Daar word aan die hand gedoen dat so 'n saak (een waar dit oor die ouer se bevoegdheid in die huislike omgewing gaan en nie oor die onderwyser se bevoegdheid in die skoolomgewing nie) 'n moeilker opgaaf aan die Hof sal bied. Eerstens sal

and, particularly, its own interpretation of the doctrine, laws and tenets of a particular religion, upon any religious group or grouping;

(b) Those religious groups or groupings should be allowed to sort out their differences regarding those aspects of the religions to which they adhere amongst themselves;

(c) Only if the solutions to their problems which are arrived at by the religious groups or groupings themselves are utterly unacceptable to the established rules and laws of the State should those solutions be ignored. Otherwise, for fear of interfering with the right of freedom of religious expression, those solutions should be respected;

(d) It is only in an extremely limited field that the secular courts should impose their rulings upon religious groups or groupings; and

(e) A secular court should rarely, if ever, hand down a ruling relating to religious doctrine.

Veral punt (e) hierbo is ter sake vir die onderhawige saak. 
die ietwat sofistiese uitweg van 'n literalistiese uitleg van godsdienstige tekste (so op die trant van dat die Bybel van ouers praat en nie van onderwysers nie) nie in so 'n geval vir die Hof beskikbaar wees nie. Tweedens sal die Hof in sodanige omstandighede verplig wees om oor hierdie omstrede aangeleentheid uitspraak te lewer in 'n konteks waar daar geen twyfel daaroor bestaan dat dit in die geding oor 'n persoon se opregte godsdienstige oortuiging gaan nie.

\subsection{Die Konstitusionele Hof se werkwyse}

\subsubsection{Artikel 36}

Anders as die Hooggeregshof, besleg die Konstitusionele Hof die appèl aan die hand van artikel 36 van die Grondwet van 1996 - die sogenaamde beperkingsartikel. Die Hof se benutting van artikel 36 is egter ongewoon, in soverre hierdie ondersoek geloods word sonder om eers ' $n$ oordeel te fel oor die vraag of ' $n$ fundamentele reg van 'n persoon in werklikheid aangetas is. ${ }^{16}$

\subsubsection{Best case-scenario}

Die Hof kies dus 'n werkwyse wat na sy oordeel die appellant in die heel gunstigste posisie plaas (par. 27). Die Hof gaan, met ander woorde, van die veronderstelling uit dat die kulturele en godsdienstige regte van CESA geskend is, maar sonder om te beslis dat sodanige skending inderdaad bewys is. Die gedagte onderliggend aan so 'n best case scenario-benadering is dat, as die appellant nie eens sy saak onder die omstandighede wat vir hom die heel gunstigste is kan bewys nie, dit onnodig sal wees om op meer omstrede kwessies in te gaan. Die eerste van hierdie omstrede kwessies is die vraag onder watter spesifieke artikel die appèl beslis moet word: is slegs artikel 31 ter sake, of moet die saak onder artikel 15(1) en 31 gesamentlik bereg word? 'n Tweede omstredenheid raak die vraag of die byhaal van artikel 31(2) met sy interne kwalifiseerder, nie by voorbaat ' $n$ ondersoek ingevolge artikel 36 onnodig maak nie.

Die Hof motiveer sy voorkeur daarvoor om hierdie best casescenario te volg, deur daarop te wys dat Suid-Afrikaanse regspraak oor godsdiensregte nog in sy kinderskoene verkeer. Hierdie toedrag van sake noop die Hof om versigtig te werk te gaan en om nie in 'n nadat daar bewys is dat ' $n$ fundamentele reg van 'n persoon aangetas is. 
te vroeë stadium uitsprake met 'n te wye toepassing te lewer nie. Dit behels 'n onderskrywing van judisiële minimalisme, ingevolge waarvan die Hof slegs beslis oor wat voor hom geplaas is en nie oor daarmee verbandhoudende sake, wat nie genoegsaam voor die Hof beredeneer is nie.

\subsubsection{Die appellant se submissie}

CESA het as appellant geredeneer dat die Hof 'n benadering van gestrenge/noukeurige toetsing (strict scrutiny) moet volg. Die implikasie hiervan sou wees dat die staat, wanneer die appellant bewys het dat die Schools Act substantief op sy opreg-gehuldigde godsdienstige oortuigings inbreuk maak, 'n dwingende staatsbelang (compelling state interest) sou moes aanvoer, waarom die staat nie bereid is om ' $n$ uitsondering of vrystelling aan die appellant van die betrokke Schools Act-bepaling toe te staan nie. Die Hof verwerp egter hierdie argument van die appellant, deur daarop te wys dat die strict scrutiny-toets wat uit die Amerikaanse reg stam (waar dit self ook heel kontroversieel is) nie in die Suid-Afrikaanse reg oorgeneem is nie (par. 29).

\subsubsection{Die Hof se keuse}

In plaas van so 'n streng toets, verklaar die Hof hom ten gunste van wat hy die genuanseerde en konteksgevoelige toets van artikel 36 van die Grondwet noem (par. 30). Hiermee word 'n rigting van paslike akkommodering (appropriate accomodation) ingeslaan. In 'n ondersoek ingevolge artikel 36 staan redelikheid en proporsionaliteit sentraal. Die Hof verwys met instemming na $S v$ Manamela and Another (Director-General of Justice intervening) (2000 (5) BCLR 491), waar verklaar is dat daar by die beoordeling van die redelikheid nie met 'n stiplys (wat die kenmerke daarvan noukeurig uiteensit) gewerk word nie, maar dat die Hof tot 'n globale waardeoordeel moet kom. (par. 31) So 'n ondersoek ontplooi aan die hand van die elemente wat in artikel 36(1) as kriteria vermeld word. Die betrokke artikel, wat in bepaalde opsigte van die ewekniebepaling in die 1993-Grondwet verskil,17 lui soos volg:

36(1) Die regte in die Handves van Regte kan slegs kragtens 'n algemeen geldende regsvoorskrif beperk word in die mate

17 Waar die staat ooreenkomstig die 1993-Grondwet moes bewys dat 'n aangevegte wetsartikel sowel redelik as noodsaaklik is, is die toets ooreenkomstig artikel 36 dié van redelikheid en regverdigbaarheid, wat minder streng is. 
waarin die beperking redelik en regverdigbaar is in 'n oop en demokratiese samelewing gebaseer op menswaardigheid, gelykheid en vryheid, met inagneming van alle tersaaklike faktore, met inbegrip van -

(a) die aard van die reg

(b) die belangrikheid van die doel van die beperking

(c) die aard en omvang van die beperking

(d) die verband tussen die beperking en die doel daarvan, en

(e) 'n minder beperkende wyse om die doel te bereik.

Die Hof gee by monde van Sachs $\mathrm{R}$ in meevoerende en gestileerde prosa18 te kenne dat godsdiensvryheid 'n belangrike reg is (par. 3638). Daar word 'n besondere poging aangewend om die leser onder die indruk te bring van hoe 'n moeilike proses dit is om in regspraak oor kwessies van geloof en godsdiens uitsluitsel te gee. Die redes wat hiervoor aangegee word, is enersyds dat die belange wat geharmoniseer moet word, naamlik staatlike en godsdienstige belange, tot twee radikaal verskillende konseptuele en eksistensiële ordes behoort. Andersyds word aangetoon dat dit moeilik is om 'n duidelike skeidslyn tussen staatlike en godsdienstige aangeleenthede te trek. Nie alleen kan oorwegings van redelikheid en geloof met mekaar in botsing wees nie, maar dit kan ook problematies wees om onderskeid te tref tussen daardie aspekte van 'n aktiwiteit wat godsdienstig van aard is en as sodanig deur die Handves van Regte beskerm word en daardie aspekte daarvan wat sekulêr van aard is en op die gewone wyse gereguleer moet word (par. 34; vgl. ook par. 15 en veral 33).

\subsubsection{Die eise van 'n grondwetlike demokrasie}

In 'n demokrasie kan daar uiteraard nie ligtelik omgegaan word met die beperking van regte nie. Die vraag wat volgens die Hof in ' $n$ demokratiese bedeling na vore tree - spesifiek in een wat gebaseer is op menswaardigheid, gelykheid en vryheid en waarin gewetensen geloofsvryheid met die nodige erns bejeën word - is in watter mate so ' $n$ demokrasie lede van godsdienstige gemeenskappe moet toelaat om vir hulleself te besluit watter wette hulle sal gehoorsaam en watter nie. Omdat 'n gemeenskap se koherensie afhang van alle "sensitive". 
deelhebbers daarvan se aanvaarding van sekere basiese norme en standaarde, kan gelowiges - aldus die Hof - nie sonder meer daarop aanspraak maak dat hulle 'n outomatiese reg daarop het om op grond van hul godsdienstige oortuigings van landswette vrygestel te word nie. Die ander kant van die munt is dat die staat moet poog om, waar dit redelikerwys enigsins moontlik is, nie die gelowige in die onbenydenswaardige posisie te plaas waar hy/sy gedwing word om te kies tussen trou aan sy/haar geloof en respektering van die reg nie (par. 35).

\subsubsection{Waardes}

Die Hof lê in sy uitspraak - soos wat in 'n ondersoek ingevolge artikel 36 en ook uit hoofde van sy grondwetlike verpligting ingevolge artikel 39(1)(a) verwag kan word - heelwat klem op waardes en die daarmee verbandhoudende regte. Die toediening van lyfstraf word getipeer as iets wat na sy aard vernederend is (par. 44 e.v.) en gevolglik indruis teen menswaardigheid wat in artikel 10 van die Handves beskerm word. Dit word ook by wyse van assosiasie in die dampkring geplaas van foltering en mishandeling. Hiermee saam moet die Handves se verbod op wrede en onmenslike strawwe (art. 12(1)(e)) in berekening gebring word. 'n Verdere kernwaarde wat in die beoordeling figureer, is dié van gelykheid (art. 1 van die Grondwet). Die Hof wys die respondent se argument, wat gebaseer is op die reg op gelykheid ingevolge artikel 9 van die Grondwet, af (par. 42).

\subsubsection{Kontekstuele oorwegings}

Kontekstuele oorwegings figureer op verskillende wyses in die uitspraak. 'n Kerntema in hierdie verband is dat die nuwe grondwetlike demokrasie, wat sedert 1994 in Suid-Afrika gevestig word, ingestel is op die vestiging van 'n daadwerklike nuwe bedeling. Die respondent beroep hom dan ook uitdruklik in paragraaf 11 op die noodsaak vir transformasie. Die teenkanting teen lyfstraf vorm deel van die afwysing van 'n kultuur van geweld en 'n bevestiging van 'n kultuur van redelikheid (par. 49); dit is 'n wending weg van 'n kultuur van outoriteit en gesag (par. 50) na een van deelname en openheid. As sodanig gaan dit hier oor 'n beginselsaak, volgens die Hof, en nie bloot oor iets administratiefs nie. Die simboliese, morele en pedagogiese doel en waarde van 'n verbod op lyfstraf moet daarom nie geringgeskat word nie (par. 50). Die Hof stel dat die staat 'n plig het om die vlak van geweld in die Suid-Afrikaanse samelewing te laat afneem (par. 47). In hierdie relaas word ' $n$ verwysing na die Soweto-opstand van 1976 bygehaal 
en word daarop gewys dat die staat in daardie geval met geweld gereageer het op redelike aansprake van die jeug. As sodanig is die Hof daarvan bewus dat dit 'n uitspraak gee in 'n konteks wat gelaai is met social pain (par. 49).

'n Volgende konteks is dié van die volkereg en die inagneming van internasionale en regionale regspraak met betrekking tot lyfstraf (par. 18, 41 en 47). Die oorwegende tendens wat uit hierdie ondersoek blyk, is dié van 'n beweging weg van lyfstraf en van 'n toenemende verbod daarop.

\subsubsection{Redelike akkommodering}

Dit is insiggewend om te let op die wyses waarop die Hof sy beslissing dat daar geen uitsondering vir CESA gemaak behoort te word nie, motiveer. Die onderliggende tema in hierdie verband, is dié van redelike akkommodering en daarbinne figureer die volgende regverdigings. Eerstens gaan dit daaroor dat regte beperkbaar is. Tweedens word daarop gewys dat die impak wat die bepaling van die Schools Act op die appellant maak, nie die kern van laasgenoemde se godsdiensvryheid aantas nie (par. 51). Die appellant kan na die oordeel van die Hof steeds op 'n aktiewe wyse 'n Christelike etos in hul skole bevorder. Al beperking wat hierop geplaas word, is dat onderwysers nie lyfstraf mag toedien nie. Derhalwe is die Hof van oordeel dat CESA nie as gevolg van die lyfstrafverbod voor 'n alles-of-niks keuse gestel word, waar hulle gedwing word om te kies tussen gehoorsaming van hul geloof en gehoorsaming van die reg nie (par. 51). Net soos wat hulle regulering in sake oor standaarde en dergelike dinge aanvaar, moet hulle in ' $n$ gees van akkommodering met hierdie beperking verlief neem.

\subsubsection{Bespreking}

'n Eerste punt van kritiek op die Konstitusionele Hof se benadering, is dat die Hof nie 'n ernstige poging aanwend om duidelik aan te dui onder watter artikel van die Grondwet dit die saak hanteer nie. Sachs $\mathrm{R}$ maak nie die onderskeid wat die Grondwet tref tussen regte, met betrekking tot godsdienstige oortuigings (art. 15(1)) en regte met betrekking tot godsdiensbeoefening (art. 31), operasioneel in die uitspraak nie. Die feit dat hy dit nie doen nie, hou gevolge in vir dit wat in die uitspraak ter sprake kom en wat nie. Dit bring byvoorbeeld mee dat die opregtheid waarmee die appellant die betrokke oortuigings huldig, buite rekening gelaat word en nie getoets word nie. Verder het dit 'n invloed op die proses wat die Hof 
volg om tot 'n beslissing te geraak. Dit is uiteraard in belang van regsekerheid dat (voornemende) litigante met redelike sekerheid weet hoe die howe te werk sal gaan as 'n dispuut oor godsdiensregte deur die howe bereg gaan word. Sodanige kennis kan ook 'n rol speel as partye oorweeg of hulle 'n redelike kans op sukses het as hulle hulle tot die howe wend, wanneer hulle van oortuiging is dat hul godsdiensregte aangetas word. Die Konstitusionele Hof het in sy uitsprake met die loop van jare riglyne neergelê vir die prosedure wat gevolg moet word as iemand van mening is dat van sy/haar regte, wat in die Handves beskerm word, geskend word. Dit behels breedweg gesproke 'n proses wat uit twee fases bestaan. In die eerste fase moet die gedingsparty wat aanvoer dat sy/haar regte geskend word, 'n prima facie saak uitmaak, dat 'n fundamentele reg deur 'n regsbepaling of deur administratiewe optrede, aangetas word. Indien daar wel sodanige prima facie aanduiding(s) is, word daar tot die tweede fase van die ondersoek oorgegaan, naamlik 'n ondersoek aan die hand van artikel 36 (Ferreira $v$ Levin and others par. 44; De Waal, Currie \& Erasmus, 2001:25, 34). Terwyl die bewyslas in die eerste fase op die persoon rus wat beweer dat sy regte geskend is, verskuif hierdie las tydens die tweede fase na die staat. Deur direk met 'n artikel 36-ondersoek weg te val, sonder om eers deur die eerste fase te gaan, wyk die Hof in die CESA-saak af van die werkwyse wat vroeër deur hom neergelê is. Dit geskied uiteraard tot nadeel van die respondent, wat nou met 'n bewyslas opgesaal word wat die appellant eintlik behoort te kwyt.

Pieterse (2001:675) lewer kritiek daarop dat 'n ondersoek ingevolge artikel 36 geloods word voordat daar behoorlik rekenskap gegee is van die trefwydte van artikel 31(2). Hy gee toe dat daar onder akademici verskil van mening is oor die fyner nuanses van die toepassing van artikel 31(2), veral met betrekking tot die verskuiwing van die bewyslas. ${ }^{19}$ Tog wys hy daarop dat skrywers dit daaroor eens is dat die artikel 31(2)-ondersoek nog deel vorm van die eerste fase van die ondersoek en nie deel uitmaak van die artikel 36-fase nie. Dit hou veral konsekwensies in vir die wyse waarop waardes in die beslissing van die Konstitusionele Hof betrek word.

19 Terwyl Woolman (aangehaal in Chaskalson et al., 1999:12.24 en 12.25) dit beskou as 'n intermediêre stap, is Carpenter $(1995: 260,262)$ van mening dat 'n verskuiwing van die bewyslas net plaasvind wanneer die interne kwalifiseerder nie deel vorm van die definisie van 'n reg nie. 
Indien artikel 31(2) in die eerste fase betrek word, en daar bevind sou word dat die godsdiensreg wat die betrokke godsdienstige gemeenskap wil beskerm, strydig is met een van die ander fundamentele regte wat in die Handves beskerm word, dan geniet die beweerde godsdienstige reg geen beskerming nie en beperk artikel 31(2) die regte van die godsdienstige gemeenskap direk (De Waal, Currie \& Erasmus, 2001:481-483; Currie, 1999b aangehaal in Chaskalson et al., 1999:35.23, 35.24). In so 'n geval is dit vir 'n Hof onnodig om tot 'n artikel 36-ondersoek oor te gaan en die redelikheid en regverdigbaarheid van die betrokke wetsbepaling te beoordeel.

In sy skerp kritiese beoordeling van die uitspraak, kom Pieterse (2001:676-677) tot die slotsom dat die Konstitusionele Hof se werkwyse in die CESA-saak nie alleen die duidelike skeiding tussen die twee fases van die ondersoek vertroebel nie, maar dat dit ook min duidelikheid bring en geen fondament lê vir die beregting van toekomstige sake nie.

Terwyl hy meen dat judisiële minimalisme meriete het vir sake wat nie pertinent voor die Hof gebring word vir beslissing nie, is Pieterse van oordeel dat die Hof in hierdie saak, weens die uitlegmetode wat hy gekies het, weggeskram het van aangeleenthede wat inderdaad voor die Hof geplaas is om oor uitsluitsel te gee. Alhoewel die leser oorvloedig bewus gemaak word van hoe 'n groot verskeidenheid waardes en belange in die balanseringsaksie ter sprake is, bly dit grootliks onduidelik hoe presies die afweging van belange gedoen is.

So ver dit judisiële minimalisme aangaan, is daar 'n bykomende oorweging wat die Hof nie vermeld nie, maar wat na my mening wel ter sake is. Daar word ter oorweging gegee dat die Konstitusionele Hof die aangepaste artikel 36-benadering volg, omdat dit ' $n$ beeld van even-handedness en redelikheid wou skep. Om 'n saak aan die hand van artikel 36 te bereg, wek ten minste die indruk by die aansoeker of appellant dat die Hof sy belange deeglik oorweeg het. Dit skep die geleentheid vir die Hof om duidelik te laat blyk dat dit nie ongevoelig is oor sake wat vir bepaalde persone na aan die hart lê nie.

\section{Slotbeskouing}

In die lig van bogenoemde bespreking, is dit duidelik dat daar teen sowel die werkwyse van die Hooggeregshof as dié van die Konstitusionele Hof kritiek ingebring kan word. Die vraag bly egter, 
watter van hierdie uiteenlopende uitlegmetodes die beskerming van persone se godsdiensregte die beste dien. ' $n$ Verwante vraag is, of enige van hierdie metodes enigsins die godsdiensregte van persone, wat met hul geloof erns maak, effektief beskerm.

As aanloop tot standpuntinname oor hierdie aangeleenthede, word die ooreenkomste en verskille tussen hierdie twee benaderings kortliks saamgevat.

Albei die benaderings neem godsdiensregte nominaal ernstig op. Die Konstitusionele Hof doen dit met 'n groter omhaal van woorde, terwyl die Hooggeregshof saakliker daarmee omgaan. Verder beoordeel albei howe die beskerming van godsdiensregte holisties, iets wat in die CESA-beslissings op 'n vorm van reading down uitloop. Die effek hiervan is dat persone se godsdiensregte beperk word.

Wat die verskille tussen die twee uitsprake aangaan, kan die volgende punte genoem word.

- Die Hooggeregshof besleg die dispuut kennelik onder artikel 31, terwyl die Konstitusionele Hof daarvan wegskram om eksplisiet te stel onder watter spesifieke artikel hy die saak beslis en uiteindelik sy toevlug tot artikel 36 neem.

- Die Hooggeregshof ekspliseer die toets wat hy gaan aanlê en toon dan heel presies en eksak aan waarom hy tot die besondere beslissing kom. In die lig van die appèl wat teen die beslissing verwag is, begelei die Hof die leser verder deur hierdie proses. Die Hof gaan verder as die eerste stap (waar die aansoek streng gesproke reeds afgewys kon word) en toon aan dat die aansoek steeds sal faal as die toets volledig toegepas sou word. Die artikel 36-ondersoek wat die Konstitusionele Hof doen, is na sy aard minder eksak. Getrou aan die oorwegings van proporsionaliteit en afweging, word 'n veelheid van belange, regte en waardes in die ondersoek bygehaal. Hoe presies die beslissing wat op 'n waarde-oordeel berus gemaak word, bly egter onduidelik.

- Daar is 'n geneigdheid tot vryblywendheid by die Konstitusionele Hof te bemerk in soverre daar 'n traagheid te bemerk is om 'n bepaalde prosedure vas te lê waarvolgens dispute oor godsdiensregte konsekwent bereg sal word. Cockrell (1996:37) het die vroeë regspraak van die Konstitusionele Hof by geleentheid as rainbow jurisprudence getipeer. Dit is ' $n$ vorm van beregting wat kwistig met waardes omgaan, maar wat nie graag spesifieke 
keuses wil maak en duidelike lyne wil trek as dit by substansie en prosedure kom nie.20 Hierdie tendens van swewende vryblywendheid, wat 'n mens as fuzzy jurisprudence sou kon kenskets, is ook daarin te bemerk dat die interpretasie van artikel 31(2) oopgelaat word. Dit is verder opmerklik dat die kwessie van die appellant se opregtheid nie in hierdie uitspraak onder die vergrootglas kom nie.

- Die Konstitusionele Hof se artikel 36-aanpak lyk met die eerste oogopslag of dit groter erns maak met persone wat op grond van hul godsdienstige oortuigings oor godsdiensregte litigeer. Dit wil voorkom of dit 'n meer akkommoderende en minder streng werkwyse is as dié wat deur Liebenberg $\mathrm{R}$ in die Hooggeregshof aan die hand gedoen is, en wel in dié sin dat dit nie in die eerste fase van ondersoek 'n oordeel fel oor die vraag of 'n litigant werklik op grond van godsdienstige oortuigings 'n bepaalde praktyk voorstaan nie. De Waal, Currie en Erasmus (2001:295) spreek die mening uit dat 'n artikel 36-benadering in die meeste sake beter behoort te werk as een wat berus op tegnieke van vermyding.

- Terwyl die Konstitusionele Hof se werkwyse verstaanbaar is in 'n vroeë fase van 'n jurisprudensie oor godsdiensregte, is dit na my mening nie een wat op die lange duur gehandhaaf kan word nie. Vroeër of later sal die werkwyse wat gevolg word by die beslegting van dispute oor godsdiensregte duidelik vasgelê moet word. Dit is hoogs wenslik dat daar groter duidelikheid moet kom oor sowel substantiewe as prosedurele aangeleenthede met betrekking tot die beregting van godsdiensregte. Potensiële litigante behoort te kan voorspel onder watter artikel van die Grondwet hul saak bereg gaan word.

Dit staan vas dat die howe uit hoofde van artikel 39(1)(a) verplig is om die waardes van die Grondwet integraal in hul uitsprake te betrek. In die CESA-saak kom die Konstitusionele Hof egter myns insiens gevaarlik naby aan wat Botha (2005:146) moral embroidery noem. Terwyl dit die bedoeling mag wees om deur sodanige

Cockrell (1996:37) wys juis daarop dat dit in konstitusionele beregting gaan oor "hard choices, where some values will have to be preferred over others [...]." Ook Pieterse (2000:317) merk op dat daar onafwendbaar keuses gemaak sal moet word tussen opponerende wêreldbeskouings, waarvan sommige op godsdiens berus en ander weer nie. Wat volgens hom belangrik is, is dat waardigheid, gelykheid en vryheid nie in dié proses verontagsaam moet word nie. 
uitspraak 'n waardediskoers te stimuleer, maak die voorspelbaarheid van die onderliggende ideologie, wat in hierdie beslissing na vore kom, die uitspraak iets soos 'n stilistiese oefening. Litigante in godsdiensaangeleenthede gaan weinig baat daarby vind om keer op keer te verneem hoe hoog die Hof hul godsdiensregte ag, as dit sou blyk dat daardie oortuigings keer op keer in die opwegingsproses deur die Hof te lig bevind word binne die konteks van 'n Grondwet, gerig deur die waardes van menswaardigheid, gelykheid en vryheid. Die retoriese effek van die hoogs-gestileerde waardediskoers sal na alle waarskynlikheid met die loop van tyd impak en oorredingskrag verloor.

Die besluit op 'n spesifieke hanteringswyse is myns insiens des te meer gerade in die lig daarvan dat die onderliggende waardestelsel van die Grondwet en die wyse waarop die Konstitusionele Hof tot dusver daarmee omgegaan het, dit taamlik voorspelbaar maak in watter rigting 'n beslissing oor 'n omstrede saak soos lyfstraf sal gaan. Die aansoek om 'n vrystelling van die verbod op lyfstraf in skole het myns insiens van meet af aan - weens die wyse waarop die howe met grondwetlike waardes omgaan - min kans op sukses gehad. 'n Streng, short shrift-benadering sou nie net eenvoudiger en korter gewees het nie, maar ook konseptueel helderder en eksakter. Dit sou ook nie oorgekom het as 'n blote strategie om persone, wat meen dat hul godsdiensregte geskend word, gelukkig te hou nie. Aan die uiteindelike beslissing self sou dit geen verskil gemaak het nie. Wat wel sou verskil het, is die bewyslas wat die betrokke partye sou dra.

Dit wil my voorkom of dit moeilik gaan wees vir persone wat hulle tot die Suid-Afrikaanse howe wend, om die godsdiensregte waaroor hulle kragtens die Grondwet beskik, te beskerm, ongeag watter van hierdie uitlegmetodes gevolg gaan word. In die geval van die metode wat die Hooggeregshof gevolg het, neig die toets om te streng te wees. Verder is die literalisme daarvan, asook die feit dat die Hof die interne samehangendheid van persone se godsdienstige oortuigings beoordeel, kritiseerbaar. In die geval van die werkwyse van die Konstitusionele Hof, is die manier waarop hierdie Hof die waardes van die Grondwet vertolk en teen mekaar afweeg, nie gunstig vir beskerming van godsdienstige en kulturele regte van godsdiens- en kultuurgemeenskappe nie.21 


\section{Geraadpleegde bronne}

BOTHA, C. 2005. Statutory interpretation: An introduction for students. 4th ed. Landsdowne: Juta.

BRADNEY, A. 2000. Faced by Faith. (In Oliver, P., Scott, S.D. \& Tadros, V., eds. Faith in law: Essays in legal theory. Oxford: Hart. p. 89-106.)

CARPENTER, G. 1995. Internal modifiers and other qualifications in the Bill of Rights - some problems of interpretation. SA Public Law/SA Publiekreg, 10:260-282.

CHASKALSON, M. et al. 1999. Constitutional Law of South Africa. Revision Service 5. Kenwyn: Juta.

COCKRELL, A. 1996. Rainbow jurisprudence. South African Journal on Human Rights, 12:1-38.

CURRIE, I. 1999a. Judicious avoidance. South African Journal on Human Rights, 15:138-165.

CURRIE, I. 1999b. Minority rights: Education, culture and language. (In Chaskalson, M. et al. Constitutional Law of South Africa. Revision Service 5. Kenwyn: Juta. 35.1-35.8.)

CURRIE, I. \& DE WAAL, J. 2005. The Bill of Rights handbook. 5th ed. Landsdowne: Juta.

DE WAAL, J., CURRIE, I. \& ERASMUS, G. 2001. The Bill of Rights handbook. 4th ed. Landsdowne: Juta.

DU PLESSIS, M. 2000. Doing damage to religious freedom: Discussion of the High Court decision of Christian Education South Africa $v$ Minister of Education of the Government of the Republic of South Africa 1999. BCLR 951 (SE). Stellenbosch Law Review, 2:295-305.

HOGG, P.W. 1992. Constitutional Law of Canada. 3rd ed. Toronto: Carswell.

HOSTEN, W.J. et al. 1995. Introduction to South African law and legal theory. Durban : Butterworths.

PIETERSE, M. 2000. Many sides of the coin: The constitutional protection of religious rights. Comparative and International Law Journal of South Africa, 33(3): 300-317.

PIETERSE, M. 2001. Religious confusion: Christian Education South Africa v Minister of Education 20004 SA 757 (KH). Tydskrif vir Hedendaags Romeins-Hollandse Reg, 64:672-678.

ROBERTSON, D. 1997. A dictionary of human rights. London: Europa Publications.

VENTER, F. 1998. The protection of cultural, linguistic and religious rights: The framework provided by the Constitution of the Republic of South Africa, 1996. SA Public Law/SA Publiekreg, 13:438-459.

VORSTER, J.M. 2004. Ethical perspectives on human rights. Potchefstroom: Potchefstroom Theological Publications.

WOOLMAN, S. 1999. Limitation. (In Chaskalson, M. et al. Constitutional law of South Africa. Revision Service 5. Kenwyn: Juta. 12.1-12.14.)

UNIVERSAL DECLARATION OF HUMAN RIGHTS. 1948. (In Patel, E.M. \& Walters, C. Human Rights:. Fundamental instruments \& documents. Durban: Butterworths. p. 3-15.)

\section{Grondwette}

Die Grondwet van die Republiek van Suid-Afrika. 1993.

The Constitution of the Republic of South Africa. 1993. 
Die Grondwet van die Republiek van Suid-Afrika. 1996.

The Constitution of the Republic of South Africa. 1996.

\section{Saakregister}

Christian Education South Africa v Minister of Education 20004 SA 757 (K).

Christian Education South Africa $v$ Minister of Education of the Government of the Republic of South Africa 199812 BCLR 1449 (K).

Christian Education South Africa v Minister of Education of the Government of the Republic of South Africa 1999 (4) SA 1092 (SE) 1999 BCLR 951 (SE).

Ferreira $v$ Levin NO and Others: Vryenhoek and Others Powell NO and Others 19961 SA 984.

Lemon v Kurtzman 1970403 US 602.

Nortje $v$ Attorney-General of the Cape 19952 SA 460 (K)

Prince $v$ President of the Law Society of the Cape of Good Hope \& Others 2002 (3) BCLR $231(\mathrm{~K})$.

Qozeleni v Minister of Law and Order and Another (1994) (1) BCLR 75 (OK).

$R v$ Big M Drug Mart 18 DLR (4th) 321, 1 SCR 295.

$S$ v Lawrence; S v Nagel; S v Solberg 19974 SA 1176 (K).

$S \vee$ Manamela and Another (Director-General of Justice intervening) 2000 (5) BCLR 491.

$S$ v Zuma and Others 1995 (2) SA 642 (K).

Worcester Muslim Jamaa v Valley and Others 2002 (6) BCLR 591 (K).

\section{Wetgewing}

The South African Schools Act. Wet 84 van 1996.

\section{Kernbegrippe:}

Christian Education South Africa

godsdiensvryheid en -regte

Grondwet, 1996: artikel 15, 31, 36

lyfstraf

uitlegmetode

vryheid van godsdiens

\section{Key concepts:}

Christian Education South Africa

Constitution, 1996: section 15, 31, 36

corporal punishment

freedom of religion

freedom of religion and rights pertaining to religion

method of interpretation 
